\title{
Effect of the Pine Cone Extract Phytochemical and Physiological activity on HaCaT Cells
}

\author{
Jin Kim ${ }^{1,5}$, Jing-Gi Park², Chang-Moon Lee ${ }^{3,4^{*}}$, Su-Gwan Kim ${ }^{1,5 *}$ \\ ${ }^{1}$ Department of Oral and Maxillofacial Surgery, College of Dentistry, Chosun University Gwangju, Korea \\ ${ }^{2}$ Moneykey Co., Ltd. Gwangju, Korea \\ ${ }^{3}$ Department of Biomedical Engineering, Chonnam National University, Yeosu-si, Jeollanam-do, Korea \\ ${ }^{4}$ Research Center of Healthcare and Biomedical Engineering, Chonnam National University, Yeosu-si, Jeollanam-do, Korea \\ ${ }^{5}$ Institute of Dental Science, Chosun University, Gwangju, Korea
}

\author{
*Corresponding author: Chang-Moon Lee, \\ Department of Biomedical Engineering, \\ Chonnam National University, 50 Daehak-ro, \\ Yeosu-si, Jeollanam-do 59626, Korea \\ Tel.: +82616597361 \\ Fax: +82616597369 \\ Email:cmlee@jnu.ac.kr \\ Su-Gwan Kim, Department of Oral and \\ Maxillofacial Surgery College of Dentistry, \\ Chosun University 399 Pilmun-daero, Dong- \\ gu, Gwangju 61452, Korea \\ Tel.: +8262 2306883 \\ Fax: +82626085407 \\ Email: cream4251@chosun.ac.kr
}

Chang-Moon Lee and Su-Gwan Kim contributed equally to this work.

Received June 25, 2019

Revised September 10, 2019

Accepted September 16, 2019

Published September 30, 2019

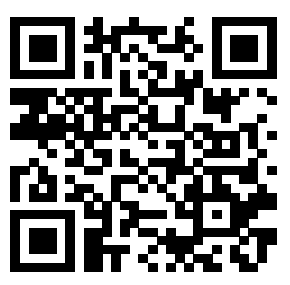

\begin{abstract}
Purpose: This study examines the properties and potential commercial value of the pine cones extract when used as bioactive and cosmetics ingredients. Methods: Pine cones were extracted with hot water (WE), $70 \%$ ethanol (EE), and supercritical fluid extraction (SFE) to examine their antioxidant properties on the basis of their total polyphenol content, 2,2-diphenyl-1-picrylhydrazyl (DPPH) radical scavenging activity, and gas chromatography-mass spectrometry (GC-MS) analysis. The antibacterial properties of the pine cone extract were also studied on 2 types of bacteria. In addition, this study examined the nitric oxide (NO) inhibition effect using RAW 264.7 cells, in which the inflammatory reaction was induced by lipopolysaccharides (LPS), and cell migration activity in the HeCaT cells. Results: The extract obtained with SFE exhibited high antioxidative ability even at low concentration $(0.125 \%)$. The antimicrobial activity of the of SFE pine cone extract was $12.1 \pm 1.04 \mathrm{~mm}$ for Staphylococcus aureus (S. aureus) and $11.8 \pm 0.45 \mathrm{~mm}$ for Staphylococcus epidermidis ( $S$. epidermidis). Cytotoxicity evaluation showed cell viability above $80 \%$ in all extracts. During the antiinflammatory test, the nitric oxide expression level was low, and it was confirmed by the antiinflammatory effect. The results of the stability test showed that emulsions containing SFE extract were very stable. The $\mathrm{pH}$ and high temperature $\left(40^{\circ} \mathrm{C}\right)$ of each emulsion containing SFE extract did not considerably change for 30 days. Conclusion: These findings suggest that SFE extract is a possible cosmeceutical material with potent skin regeneration and antiinflammatory properties.
\end{abstract}

Keywords: Pine cones, Phytochemical, Supercritical fluid extraction, Antiinflammatory, Cosmeceutical

\section{Introduction}

최근에는 화장품, 생의학 분야에 많은 관심을 갖게 되면 서 바이오 기술이 비약적인 발전을 가져오고 있다. 특히, 국내 외 천연물의 기능성 성분을 탐색해 차별화된 화장품원료를 개 발하고, 그 효과를 평가하는 기술 또한 크게 발전했으며, 단
순히 화장품의 기능을 벗어나 화장품(cosmetic)과 의약품 (pharmaceutical)의 합성어인 cosmeceutical 제품이 활발히 연구되고 있다.

솔방울(pine cone)은 소나무의 방울 열매로 송구(松球), 송 실(松實)이라고도 부르며 열매의 송이씨앗이 들어 있는 자그마 한 비늘들이 둥글게 모인 형태를 갖고 있다. 솔방울은 습도에 
따라 비늘을 펼치거나 접으며, 습도가 낮을수록 펼쳐지고, 습도 가 높을수록 천산갑처럼 움츠리는 형태를 지닌다(Choi et al., 2014). 구성 성분으로 수분, 당질, 섬유소 외에 소량의 단백질, 지질, 회분 등이 알려져 있으며 솔잎, 솔방울, 송진 껍질 등 모 든 부위가 약용 및 건강식품으로 이용되고 있다. 소나무를 이 용한 농약, 의약, 향료, 항균제 등의 상업적 가치가 있는 제품 으로 개발하기 위하여 유효성분의 분리 정제 기술 발전에 관한 많은 연구가 수행 되고 있다(Carson et al., 2011; Hong et al.,2004)

대부분의 식물에서 추출한 각종 화합물들의 함량은 식물의 부위와 생육환경 및 수확시기에 따라 다르지만 동일한 종류의 식물에서는 화합물의 종류는 거의 동일하게 추출된다.

특히, 추출방법에 따라 성분의 함량과 순도가 달라지며 고가 의 천연 의약품 추출 및 정제에 응용되는 유기용매의 문제점을 극복하는 방법으로 용매 회수가 용이하고 잔존하는 용매가 없 는 초임계 추출법(supercritical fluid extract)이 상업적으로 유용하다. 초임계 유체는 액체와 기체의 특성을 동시에 가지는 임계 온도와 압력이상에서 단일상으로 존재하는 유체를 의미한 다. 초임계 상태의 물질은 임계점 부근에서 온도와 압력을 변화 시키면 물리, 화학적 성질을 연속적으로 변화시킬 수 있다. 초 임계 유체는 주로 이산화탄소 혹은 이산화탄소와 소량의 보조 용매로 조성되고 임계온도와 압력이 낮아 온화한 조건에서 추 출을 수행할 수 있다. 또한 독성, 가연성, 추출 대상 물질과 반 응성 및 부식성이 없기 때문에 추출용매로 이산화탄소가 보편 적으로 이용되고 있으며 추출물은 식품, 화장품, 의약품등에 다 양하게 활용할 수 있다(Hwang et al.,2017).

기존 연구 결과에 따르면 솔방울 추출물에 polyphenollignin 성분은 항알러지 및 면역계 질환에 효과가 좋으며 항산 화 및 항균효과가 보고되고 있다(Jeong et al., 2014).

소나무과의 정유 성분은 많은 연구가 되어 있지만 국내에 가 장 많이 자생하는 적송 솔방울의 초임계 추출물의 성분 연구는 미비하다.

본 연구에서는 적송의 솔방울을 초임계추출방법으로 얻은 추 출물의 성분 분석을 통해 화장품으로 활용 가능성을 살펴보고 화장품 산업에 활용가능성을 평가하고자 한다.

\section{Method}

\section{1. 추출물 준비}

본 실험에 사용한 솔방울은 충북 괴산에 있는 적송소나무로부 터 채취한 것을 시료로 사용 하였다. 솔방울은 증류수로 세척하여 열건조기에서 건조하였다. 분쇄한 솔방울은 열수 추출, 주정 추 출, 초임계 추출 3 가지 방법으로 추출 하였다. 열수추출(water extract, WE)은 솔방울 분쇄물 $30 \mathrm{~g}$ 을 증류수 $300 \mathrm{~mL}$ 를 넣은 후 열을 가하여 $100^{\circ} \mathrm{C}$ 로 유지하면서 교반기에서 $6 \mathrm{~h}$ 동안 추출하였다. 추출이 완료된 후에는 농축액을 원심분리하 여 상층액을 동결건조하여 분말형태로 제조하였다.

주정추출 (ethanol extract, $\mathrm{EE}$ )은 회전 진공 농축 추출기를 이용하여 솔방울 분쇄물 $30 \mathrm{~g}$ 을 농축 추출조에 $70 \%$ 에탄올 300 $\mathrm{mL}$ 를 넣은 후 열을 가하여 $100^{\circ} \mathrm{C}$ 로 유지하면서 항온수조에서 2 $\mathrm{h}$ 동안 추출하였다. 추출이 완료된 후에는 에탄올을 탈기시켜 동 결건조 후 분말형태로 제조하였다.

초임계 추출(supercritical fluid extract, $\mathrm{SFE}$ )은 장성 나노바 이오센터내에 구비된 초임계 유체추출장치 $\left(\mathrm{SC}-\mathrm{CO}_{2}\right.$ extraction system; Ilshin Autoclave, Korea)를 이용하였다. 건조시킨 솔방 울을 100 mesh로 분쇄하여 솔방울 $500 \mathrm{~g}$ 을 반응기에 주입 후 압 력 $400 \mathrm{bar}$, 온도 $50^{\circ} \mathrm{C}$, 보조용매에탄올 유량은 $3 \mathrm{~mL} / 60 \mathrm{~min}$ 의 조건에서 총 $4 \mathrm{~h}$ 동안 추출하였고, 분리조 압력은 $40 \mathrm{bar}$, 온도 $40^{\circ} \mathrm{C}$, 이산화탄소 $\left(\mathrm{CO}_{2}\right)$ 유량은 $60 \mathrm{~mL} / 1 \mathrm{~min}$ 의 조건에서 추출 하였다.

\section{GC-MS분석}

$\mathrm{WE}, \mathrm{EE}, \mathrm{SFE}$ 로 얻은 추출물의 성분을 분석하기 위해 $\mathrm{GC}-\mathrm{MS}$ 장비(GC-2010; Shimadzu Co., Japan)를 이용하였다. 각 추출 물을 $\mathrm{DMSO}$ 에 충분히 교반한 후, 원심분리기를 이용하여 부유물 을 제거하고 마이크로 필터 $(0.45 \mu \mathrm{m})$ 로 여과하여 시료를 준비하 였다. 컬럼은 $\mathrm{BD}-5(60 \mathrm{~mm} \times 0.25 \mathrm{~mm} \times 0.25 \mathrm{~mm})$, carrier gas는 He으로 flow rate $1 \mathrm{~mL} / \mathrm{min}$, injection 온도는 $250^{\circ} \mathrm{C}$, split ratio $10: 1$, oven 온도는 $50-300{ }^{\circ} \mathrm{C} / 3^{\circ} \mathrm{C}$ 승온, injection volume은 $1 \mu \mathrm{L}$ 조건으로 성분분석을 하였으며, mass selective detector (MSD)에서 mass range 28-550, acquisition mode는 scan mode 조건으로 성분들을 정량하였다.

\section{3. 생리활성 평가}

추출한 시료 $0.5 \mathrm{~g}$ 을 용매 $10 \mathrm{~mL}$ 를 넣고 $20 \mathrm{~min}$ 간 진탕 후 $10 \mathrm{~min}$ 간 원심분리하여 종이여과지로 3 회 추출한 다음 최종 부 피를 $50 \mathrm{~mL}$ 로 정용하였다. 추출물 $100 \mu \mathrm{L}$ 에 $2 \% \mathrm{Na}_{2} \mathrm{CO}_{3} 2 \mathrm{~mL}$ 를 가하고 vortex 한 후 $2 \mathrm{~min}$ 방치한다. $50 \%$ folin-ciocalteau's phenol reagent $100 \mu \mathrm{L}$ 를 첨가하고 vortex하여 $30 \mathrm{~min}$ 방치 한 다음 $750 \mathrm{~nm}$ 에서 흡광도를 측정한다. Gallic acid (GAE; Sigma-Aldrich, USA)를 0-200 $\mu \mathrm{g} / \mathrm{mL}$ 의 농도로 제조하고 시 료와 동일한 방법으로 분석하여 얻은 표준 검량선으로 시료추출 물의 총 페놀 함량을 산출하였고, gallic acid equivalents $(\mathrm{mg}$ $\mathrm{GAE} / \mathrm{g}$ extract)로 나타내었다.

항산화 효과를 측정하기 위한 전자공여능을 측정하였다. 각 시 료용액 $2 \mathrm{~mL}$ 에 $0.2 \mathrm{mM}$ 의 $\mathrm{DPPH} 1 \mathrm{~mL}$ 넣고 교반 한 후 $30 \mathrm{~min}$ 암실에서 방치한 후 $517 \mathrm{~nm}$ 에서 흡광도를 측정하였다. 전자공여 
능은 시료용액의 첨가군과 무첨가군의 흡광도 감소율로 나타내었 다.

\section{$\mathrm{A}:$ 대조군의 흡광도( $\mathrm{DPPH}$ 용액)}

$\mathrm{B}$ : 샘플의 흡광도

Free radical scavenging effect $(\%)=[1-(\mathrm{B} / \mathrm{A})] \times 100$

항균활성은 배지평판법(disc diffusion assay)으로 생육저 해(clear zone)환을 확인하였다. 실험에 사용한 균주는 한국세 포주은행(KCLB)에서 분양 받아 배양하여 사용하였다. 항균시 험용 평판배지는 계대 배양된 Staphylococcus aureus $(S A)$ 와 Staphylococcus epidermis $(S E)$ 를 $100 \mu \mathrm{L}$ 씩 도말하여 액체 배 지에 용해시킨 추출물(WE, $\mathrm{EE}, \mathrm{SFE}) 1 \%$ 를 paper disc $(6 \mathrm{~mm}$; diameter)에 천천히 흡수시킨 뒤 건조과정을 거쳐 평판배지 위 에 밀착시킨 상태로 $37^{\circ} \mathrm{C}$ 에서 $24 \mathrm{~h}$ 배양한 후 disc 주변에 생성된 clear zone을 측정하여 항균활성을 비교하였다.

\section{4. 세포생존률 평가}

시료의 세포 독성 평가는 ISO 10993-3방법에 따라 진행하 였다. 대식세포 계열(Murine macrophage cell line)인 RAW 264.7세포는 American Type Culture Collection (ATCC; Manassas, USA)에서 구입하여 실험에 사용하였다. 생존율은 3-(4,5-dimethylthiazol-2-yl)-2,5-diphenyl tetrazolium bromide (MTT) 방법으로 측정하였다. 추출물을 dimethyl sulfoxide (DMSO; Sigma-Aldrich, USA)에 먼저 녹인 후 세포 배양 배지에 희석하여 농도별로 처리하였다. 96 well plate에 $1 \times$ $10^{4} \mathrm{cell} / \mathrm{mL}$ 의 농도로 RAW 264.7 세포를 분주하여 세포배양기 $\left(37^{\circ} \mathrm{C}, 5 \% \mathrm{CO}_{2}\right)$ 에서 안정화 시킨 후 농도별로 추출물을 처리하 여 $24 \mathrm{~h}$ 배양하였다. 그 후 MTT시약을 처리하고 생존 세포의 효 소작용에 의해 환원되도록 $3 \mathrm{~h}$ 더 배양한 후 배양액을 제거하고 각 well에 $\mathrm{DMSO}$ 를 첨가하여 생성된 formazan 결정을 녹인 다음 Microplate reader (BioTek, US)를 이용하여 $560 \mathrm{~nm}$ 에서 흡광 도를 측정하였다.

\section{5. 항염증 평가}

Macrophage RAW 264.7 세포로부터 생성된 NO의 양은 세 포 배양액 중에 존재하는 $\mathrm{NO}_{2}{ }^{-}$를 griess 시약을 이용하여 측정하 였다. 세포배양 상등액 $100 \mu \mathrm{L}$ 와 griess시약 $100 \mu \mathrm{L}$ 을 혼합하 여 반응하여 $10 \mathrm{~min}$ 동안 반응시킨 후 $540 \mathrm{~nm}$ 에서 Microplate reader (BioTek, US)를 이용하여 흡광도를 측정하였다. $\mathrm{NO}_{2}^{-}$의 양은 $\mathrm{NaNO}_{2}$ 의 표준곡선을 이용하여 정량하였다.

\section{6. 세포이동률 평가}

추출물의 세포이동 촉진 여부를 평가하기 위해 48 well plate 에 $5 \times 10^{4} \mathrm{cells} / \mathrm{mL}$ 의 농도로 $\mathrm{HaCaT}$ 세포를 분주하여 세포배양 기 $\left(37^{\circ} \mathrm{C}, 5 \% \mathrm{CO}_{2}\right)$ 에서 안정화 시킨 후 $24 \mathrm{~h}$ 배양한 후, 세포단층
에 p200 pipet tip으로 scratch를 가해 빈 공간을 만들고, 혈청을 포함하지 않은 배지를 가해 $24 \mathrm{~h}$ 배양하여 각 실험군 $(\mathrm{WE}, \mathrm{EE}$, $\mathrm{SFE}) 0.5 \%$ 농도의 추출물을 처리하여 세포이동 정도를 inverted microscope (CKX53; Olympus-Scope, Japan)를 이용해 대조 군과 비교하였다.

\section{7. 추출물함유 에멀젼제조 및 안정성평가}

솔방울 추출물을 함유한 emulsion을 제조하였다(Table1), 수상 과 유상을 나누어 $80^{\circ} \mathrm{C}$ 까지 가열하여 용해시킨 후, homomixer (X1030D; CAT Co., Germany)를 이용하여 5,000 rpm에서 15 $\min$ 간 1 차 유화하고, $40^{\circ} \mathrm{C}$ 까지 냉각 하여 2 차 유화 하였다. $\mathrm{WE}$, $\mathrm{EE}, \mathrm{SFE}$ 추출물 $0.5 \%$ 을 넣고 $3,000 \mathrm{rpm}$ 에서 $5 \mathrm{~min}$ 유화하고 $30^{\circ} \mathrm{C}$ 까지 냉각시켰다.

추출물이 함유된 에멀젼의 $\mathrm{pH}$ 안정성은 $25^{\circ} \mathrm{C}$ 에 보관한 emulsion을 pH meter (Metrohm 691, Metrohm UK)를 이용하 여 측정하였다. 온도에 따른 안정성 시험법은 온도 $0,25,40^{\circ} \mathrm{C}$ 에 서 보관하여 경시적 변화에 따른 상태 변화를 육안으로 평가하였 다(Zuo et al., 2017).

\section{8. 통계처리}

본 연구의 모든 실험결과는 3 회 반복하여 측정하였으며 평균값 (mean)과 표준편차(standard deviation, $\mathrm{SD}$ ) 로 나타냈다. 대조 군과 실험군 사이의 통계학적 유의성 검정은 Student's $t$-test로 비교하였으며 $p$ 가 0.05 이하인 것과 0.01 이하인 것만 유의한 것으 로 하였다.

\section{Results and Discussion}

\section{1. 추출물의 수율}

나무에서 채취한 솔방울은 실험에 사용하기 위해 수세 후 건조 전과 후를 측정한 결과 솔방울의 수분 함량은 $11.2 \pm 2.1 \%$ 로 측정 되었다. 추출 방법에 따른 솔방울 추출 수율은 각각 $\mathrm{WE} 23.32 \%$, $\mathrm{EE} 32.12 \%, \mathrm{SEF} 20 \%$ 로 확인되었다.

증류추출과 용매추출법에 사용되는 열처리는 휘발성물질에 영 향을 주는 단점과 용매 사용 경우 유기용매가 잔류하는 문제점을 가지고 있다. $\mathrm{SFE}$ 추출방식은 추출량이 많지 않지만 유효성분의 순도 및 정제가 가능하여 선택적 추출이 가능한 장점을 가지고 있 다(Palmer \& Ting, 1995).

\section{GC-MS성분평가}

세가지 방법으로 추출하여 얻은 시료의 유효성분을 $\mathrm{GC}-\mathrm{MS}$ 로 분석하였다. $\mathrm{WE}$ 방법으로 얻은 시료의 성분 분석 결과 페놀 화합물인 quinic acid (23.54\%)와 methyl mannose (20.12\%), 
methyl glucose (22.86\%)가 주요 화합물로 확인되었다(Table 1). 솔방울은 목질인 셀룰로오스로 구성되어 있어 $\mathrm{WE}$ 추출에서 단 당류 성분이 확인되었다.

$\mathrm{EE}$ 방법으로 추출한 경우 송향 화합물로 알려진 abietic acid (22.66\%)와, 항염증 효능을 가진 kauran 화합물(6.71\%)이 확인 되었다. 또한, Vitamin A인 retinol acetate (2.78\%)와 나무껍질 에서 추출되는 digitoxigenin, stigmast 성분도 미량 확인되었다 (Table 1).

$\mathrm{SFE}$ 방법의 경우 대부분이 지용성 성분의 화합물이 관찰되었 다(Cheng et al., 2015). 바이오 활성 물질이며 천연항생제 및 항염증제로 알려진 andrographolide (1.84\%), pimara-8 (14), 15-dien-19-oicacid (5.84\%), 17-(acetyloxy)-kauran18-al (1.47\%)의 디테르펜 성분이 확인되었다. 약물로 쓰이 는 phenanthrene $(7.72 \%)$ 계 알칼로이드 성분과 지용성 비타민 retinol acetate $(40.06 \%)$ 화합물이 가장 많이 추출된 것을 확인 하였다(Table1, Figure 1).

송진의 주성분을 이루는 유기산 abietic acid화합물의 경우 WE 에서 methyl-abietate (1.19\%), EE에서 dehydro abietic acid, methyl abietic acid (22.66\%)가 확인되었으며, SFE방법으로 추
출한 경우 abietic acid (21.73\%)가 확인되었다. Abietic acid 화 합물은 현재 국내외 화장품 제조 시 사용 가능한 식물성 소재로 안정제, 피막형성제로 사용 가능하며 화장품 제형에 따라 사용 가 능할 것으로 사료된다. 피부에 여러 가지 효능을 발휘하는retinol acetate는 노화와 관련된 제품에 활용되고 있으며 $\mathrm{SFE}$ 방법으로 추출한 솔방울은 기능성 화장품에 활용 가능이 확인되었다.

\section{3. 추출물의 생리활성 평가}

식물에 존재하는 폴리페놀 화학물질은 phenolic hydroxyl 기를 가지고 있는 화합물로 플라보노이드, 안토시아닌, 탄닌, 카테킨 등을 총칭하며 색소, 떫은맛, 쓴맛 등의 성분이 되는 화합물의 총 칭이다. 플라보노이드는 페놀 화합물 범주 안에 속하고 식물계의 잎, 꽃, 과실, 줄기 및 뿌리 거의 모든 부분에 존재하며 reactive oxygen species (ROS)를 제거하는 항산화를 비롯하여 항바이러 스, 항염증, 항암 등과 같은 생리활성에 효과가 있다(Lee et al., 2012). 식물계에 널리 분포되어 있는 2 차 대사산물 페놀 화합물 과 플라보노이드 함량을 통해 항산화 활성의 간접적인 지표로 활 용되고 있다. 추출방법에 따른 폴리페놀함량을 측정한 결과 $\mathrm{WE}$

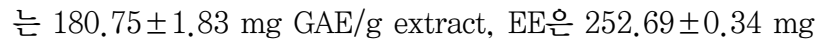

Table 1. Chemical compositions of pine cones of WE, EE and SFE by GC-MS analysis

\begin{tabular}{|c|c|c|c|c|c|}
\hline \multirow{2}{*}{ Peak } & \multirow{2}{*}{ Compound name } & \multirow{2}{*}{$\begin{array}{l}\text { Real time } \\
\text { (min) }\end{array}$} & \multicolumn{3}{|c|}{ Content (\%) } \\
\hline & & & WE & $\mathrm{EE}$ & SFE \\
\hline & Solvent (DMSO) & 15.41 & 17.32 & 36.49 & 5.24 \\
\hline 1 & Catechol & 15.05 & 3.72 & & \\
\hline 2 & 5-APDB & 15.26 & 2.08 & - & - \\
\hline 3 & 2-Methoxy-4-vinylphenol & 16.64 & 1.87 & - & - \\
\hline 4 & Silane & 20.59 & 3.25 & - & - \\
\hline 5 & 5,5-Dimethyl-1,5-oxasilonan-9-one & 20.74 & 1.02 & - & - \\
\hline 6 & Methylmannose & 22.17 & 20.12 & - & - \\
\hline 7 & Quinic acid & 22.80 & 23.54 & - & - \\
\hline 8 & Methylglucose & 25.91 & 22.86 & - & - \\
\hline 9 & Phenanthrene carboxylic acid & 33.62 & - & - & 2.92 \\
\hline 10 & Pimara-8(14),15-dien-19-oicacid & 34.53 & - & - & 5.84 \\
\hline 11 & Cycloheptane & 34.76 & - & 4.84 & - \\
\hline 12 & Naphthalene & 35.99 & - & - & 13.18 \\
\hline 13 & Andrographolide & 35.61 & 1.31 & - & 1.84 \\
\hline 14 & Androstatriene & 36.36 & - & 2.12 & - \\
\hline 15 & Phenanthrenemethanol & 36.50 & 1.72 & - & 7.72 \\
\hline 16 & Abietic acid & 37.16 & 1.19 & 22.66 & 21.73 \\
\hline 17 & Retinol acetate & 37.54 & - & 2.78 & 40.06 \\
\hline 18 & Kaura-5,16-dien-18-ol & 40.92 & - & 6.71 & 1.47 \\
\hline 19 & Medroxyprogesterone acetate & 41.68 & - & 1.51 & - \\
\hline 20 & Digitoxigenin & 42.35 & - & 1.33 & - \\
\hline \multirow[t]{2}{*}{21} & Sitosterol & 48.03 & - & 1.16 & - \\
\hline & & 60 & 100 & 100 & 100 \\
\hline
\end{tabular}

Content $(\%)=$ peak area of each compound/peak area of internal standard X100.

WE, water extract; EE, ethanol extract; SFE, supercritical fluid extract; DMSO, dimethyl sulfoxide. 


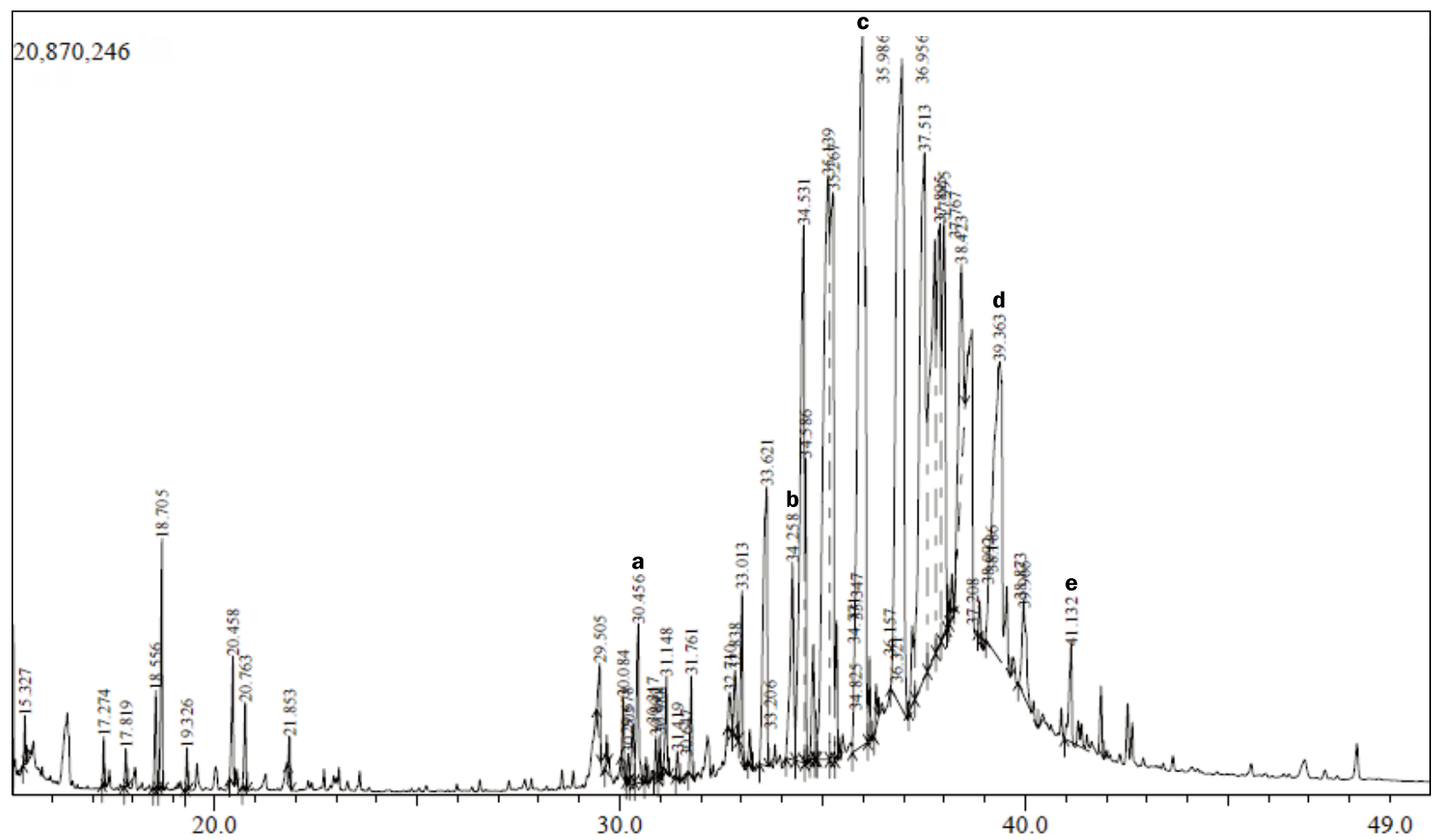

Figure 1. GC-MS graph of pine cone extracts of SFE.

Bioactive compounds extracted from different extracts of pine cone were identified based on retention time on BD-5 column and matching of the spectra with computer software data of standards (data of GC-MS systems). a, andrographolide (1.84\%); b, pimara-8(14), 15dien-19-oicacid (5.84\%); c, retinol acetate (40.06\%); d, phenanthrene (7.72\%), e, 17-(acetyloxy)-kauran-18-al (1.47\%). GS-MS, gas chromatography-mass spectrometry; SFE, supercritical fluid extract.

$\mathrm{GAE} / \mathrm{g}$ extract 함량을 나타내었다. SFE은 $270.10 \pm 0.97 \mathrm{mg}$ $\mathrm{GAE} / \mathrm{g}$ extract로 가장 높은 함량을 나타냈다.

기존 연구에서 솔방울을 $70 \%$ 에탄올로 2 회 반복하여 추출한 경 우 $232.99 \pm 0.18 \mathrm{mg} \mathrm{GAE} / \mathrm{g}$ extract 함량이 보고되었으며 열 수 추출한 시료에서도 $185.24 \pm 0.18 \mathrm{mg} \mathrm{GAE} / \mathrm{g}$ extract의 폴리 페놀 함량이 산출되었다(Ryu et al., 2017). 본 연구와는 다소 차 이가 있는 것으로 나타났는데, 이는 시료 채취시기와 지역의 고도 및 온도 등의 차이에 기인하는 것으로 판단된다.

\section{4. 항산화능평가}

짙은 자주색을 띄는 $\mathrm{DPPH}$ 는 비교적 안정한 자유라디칼(free radical)로서 항산화제, 방향족 아민류 등에 의해 환원되어 색이 탈색되는데, 이것은 다양한 천연소재로부터 항산화 물질을 검색 하는데 많이 활용되고 있다(Marxen et al., 2007). WE 추출방 법을 제외한 $\mathrm{EE}$ 와 $\mathrm{SFE}$ 추출방법에서 높은 소거활성을 보였다 (Figure 2). WE 추출물은 $0.125 \%$ 에서 $47.17 \pm 0.79,0.25 \%$ 에서 $51.41 \pm 1.05 \%, 0.5 \%$ 에서 $59.6 \pm 1.05,1 \%$ 에서 $75.42 \pm 1.8 \%$ 소거능을 관찰하였다. $\mathrm{EE}$ 과 $\mathrm{SFE}$ 추출물은 $0.125 \%$ 에서 $115 \pm$ $7.79 \%$ 와 $117 \pm 17.19 \%$ 로 저농도에서 높은 소거능을 확인할 수

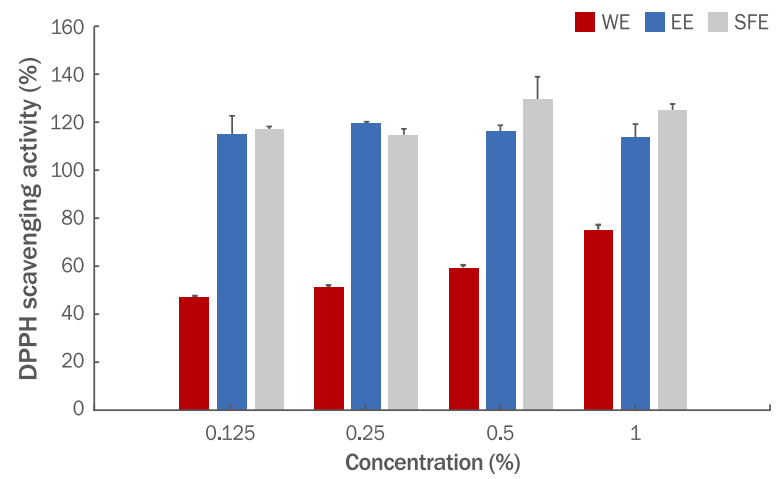

Figure 2. DPPH radical scavenging activity of WE, EE and SFE extracts from pine con.

The free radical scavenging activity of the extract was measured in terms of radical scavenging ability using the stable free radical DPPH. Briefly, $2 \mathrm{~mL}$ of various concentrations of extract in methanol (from 0.125 to $1 \%$ ) were added to $1 \mathrm{~mL}$ of $0.2 \mathrm{mM}$ DPPH solution. The plate was incubated for $30 \mathrm{~min}$ in the dark at ambient temperature and the absorbance was recorded at $517 \mathrm{~nm}$ using a spectrophotometer. Each value presents the mean $\pm S D(n=3)$. DPPH, 2,2-diphenyl-1-picrylhydrazyl; WE, water extract; $\mathrm{EE}$, ethanol extract; SFE, supercritical fluid extract. 


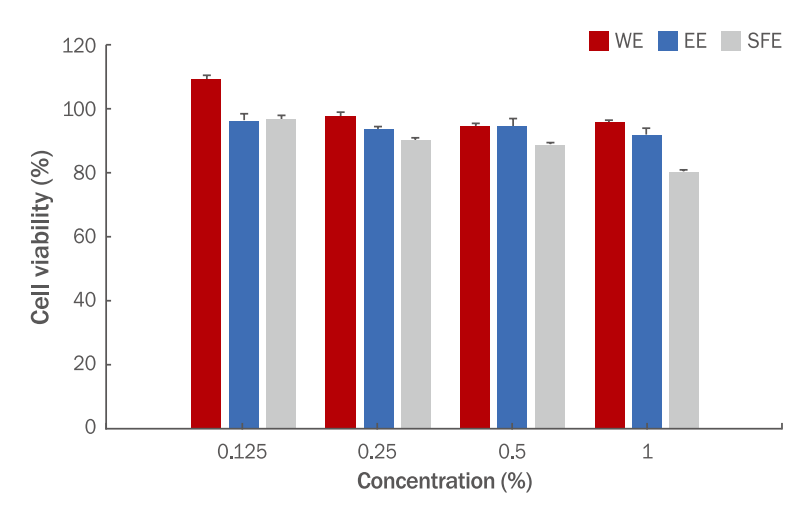

Figure 3. Effects of WE, EE and SFE on cell viability in RAW 264.7 cells.

RAW 264.7 cells were pre-treated with the different concentration of WE, EE and SFE for $24 \mathrm{~h}$. MTT (to final concentration of 0.5 $\mathrm{mg} / \mathrm{mL}$ ) was added to each well, and incubated for $4 \mathrm{~h}$ at $37^{\circ} \mathrm{C}$. The metabolically active cells reduced the MTT to blue formazan crystals, which were dissolved in DMSO. Absorbances were measured at $560 \mathrm{~nm}$. The data shown are means \pm SD of three independent experiments. No significant alteration of cell viability was observed in extract treatment. WE, water extract; EE, ethanol extract; SFE, supercritical fluid extract; MTT, 3-(4,5-dimethylthiazol2-yl)-2,5-diphenyl tetrazolium bromide; DMSO, dimethyl sulfoxide.

있었다. 항산화에 작용하는 유기화합물들이 유기용매와 초임계 장 치를 활용하여 얻은 추출물에서 다량 추출되는 것을 확인할 수 있 었다.

\section{5. 항균력 평가}

솔방울의 항균활성은 disc diffusion assay로 $\mathrm{SA}$ 와 $\mathrm{SE}$ 에서 추 추물의 항균효과를 비교하였다(Table 2). WE 추출물의 clear zone 은 $\mathrm{SA}$ 에서 $7.2 \pm 0.24 \mathrm{~mm}, \mathrm{SE}$ 에서 $6.8 \pm 0.74 \mathrm{~mm}$ 의 항균활성 을 보였다. $\mathrm{EE}$ 추출물은 $\mathrm{SA}$ 에서 $9.6 \pm 0.86 \mathrm{~mm}, \mathrm{SE}$ 에서 $8.2 \pm$ $0.36 \mathrm{~mm}$ 의 clear zone을 보였다. $\mathrm{SFE}$ 추출물은 $\mathrm{SA}$ 에서 $12.1 \pm$ $1.04 \mathrm{~mm}, \mathrm{SE}$ 에서 $11.8 \pm 0.45 \mathrm{~mm}$ 의 clear zone을 나타내어 $\mathrm{WE}$ 와 $\mathrm{EE}$ 추출물보다 높은 항균 활성을 보였다.

\section{6. 세포 생존율}

MTT assay는 96-well plate를 사용하며 검사결과를 ELISA를

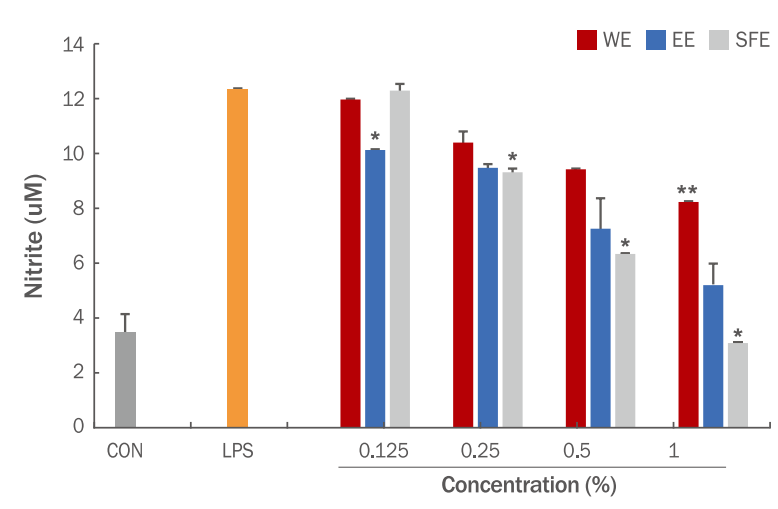

Figure 4. Effects of WE, EE and SFE on NO production level in LPS-induced RAW 264.7 cells.

The cells were pre-treated with the various concentrations of extracts for $2 \mathrm{~h}$ and then treated with LPS $(1 \mu \mathrm{g} / \mathrm{mL}$ ) for $24 \mathrm{~h}$. The amounts of NO were determined by Griess assay. The data shown are means \pm SD of three independent experiments. ${ }^{* *} p<0.01$, ${ }^{*} p<0.05$ compared with only LPS treated group. WE, water extract; $\mathrm{EE}$, ethanol extract; SFE, supercritical fluid extract; NO, nitric oxide; LPS, lipopolysaccharides.

이용하여 많은 시료를 간단하게 판독할 수 있어 세포독성 및 세포 증식 검색법으로써 널리 사용되고 있는 방법 중의 하나이다. MTT assay는 세포 내 미토콘드리아의 탈수소 효소 작용(dehydrogenase) 에 의해 생성되는 자주색 fomazan 측정을 통해 평가된다(Berridge $\& \operatorname{Tan}, 1993)$. Figure 3은 솔방울 추출물의 농도에 따른 안정성을 관찰하기 위하여 MTT assay 결과이다. WE 추출물의 경우 $0.125 \%$ 에서 $100 \%$ 이상이 넘는 증식율이 관찰되었다. $\mathrm{EE}$ 추출물에서 $90 \%$ 가 넘는 세포생존율을 관찰하였고 $\mathrm{SFE}$ 추출방법에서 얻은 시료 경 우 $1 \%$ 의 농도에서 $80.1 \%$ 세포생존율을 관찰하였다.

\section{Nitric oxide 활성도 측정}

그람 음성균의 외막성분인 lipopolysaccharide (LPS)는 대식세포 의 감염초기에 반응하고 숙주 방어에 중추적인 역할을 하나, 과도 한 LPS 자극은 대식세포에서 tumor necrosis factor- $\alpha$ (TNF- $\alpha)$, interleukin $(\mathrm{IL})-1 \beta$ 및 $\mathrm{L}-6$ 와 같은 전염증성 매개물질을 분비시 키며, nitric oxide (NO), prostaglandin $\mathrm{E} 2$ ( $\mathrm{PGE} 2$ )등의 염증매개 물질을 분비시킨다(Cho \& Kim, 2016). NO는 대식세포가 활성화되

Table 2. Disc diffusion method of antibacterial against SA and SE after $24 \mathrm{~h}$

\begin{tabular}{ccr}
\hline Sample & \multicolumn{1}{c}{ Clear zone diameter (mm) } \\
\cline { 2 - 3 } WE & $S A$ & $6.8 \pm 0.74$ \\
EE & $7.2 \pm 0.24$ & $8.2 \pm 0.36$ \\
SFE & $9.6 \pm 0.86$ & $11.8 \pm 0.45$ \\
\hline
\end{tabular}

SA, Staphylococcus aureus; SE, Staphylococcus epidermidis; WE, water extract; EE, ethanol extract; SFE, supercritical fluid extract. Paper disc diameter: $6 \mathrm{~mm}$. 

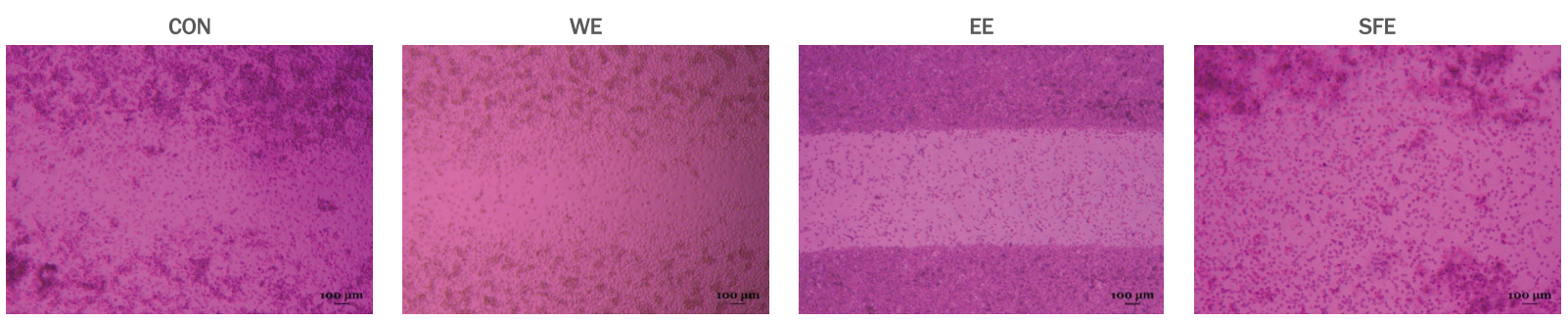

Figure 5. Effect of pine cone extracts on cell migration.

Confluent monolayers of fibroblast cells were wounded using a pipette tip, and the monolayer cells were treated with extract at the indicated concentrations. The areas of cell-free wounds were photographed in inverted microscope after $24 \mathrm{~h}$ treatment.

면 inducible NO synthase (iNOS)로부터 생산되며 박테리아를 죽 이거나 종양을 제거하는 역할도 하지만, 과도한 생성은 염증을 유발 시켜 조직의 손상, 유전자 변이 및 신경손상을 일으키는 것으로 알 려져 있다(Park et al,. 2012). NO 생성량을 알아보기 위해 nitric oxide assay를 수행한 결과 LPS만 단독으로 처리했을 때 NO 생성 량이 negative control에 비해 약 3 배 이상 증가하였으며, $\mathrm{WE}, \mathrm{EE}$ 와 $\mathrm{SFE}$ 을 농도별로 처리 하였을 때 추출물 모두 농도 의존적으로 유 의적으로 NO 생성량이 감소하였다(Figure 4).

\section{8. 세포이동(cell migration)}

세포단층(cell monolayer)에 scratch를 가하면 주변의 세포들은 세포 증식과 이동을 통해 손상된 부위를 복구하게 된다. 즉 세포이 동은 세포증식과 함께 창상치유 과정에서 큰 의미를 갖는다(Liang et al., 2007). 솔방울 추출물(WE, $\mathrm{EE}, \mathrm{SFE})$ 이 상처 치유에 도움 을 주는 지의 여부를 실험실적으로 검증하기 위해 추출물이 세포 성장과 이동에 미치는 영향을 평가하였다. In vitro 상처 치유 실 험 중 직접적이고 경제적인 평가법으로 인정받고 있는 cell scratch assay를 이용하여 세포이동 촉진 효과를 평가하였다(Justus et al., 2014). 그 결과 솔방울 추출물을 $\mathrm{WE}, \mathrm{EE}$ 방법으로 추출한 그 룹에서는 $\mathrm{SFE}$ 로 추출한 추출물보다 세포 증식이나 이동률이 느리 게 이동하는 반면 $\mathrm{SFE}$ 로 얻은 추출물을 처치한 실험군은 대조군에 비해 scratch wound가 빠르게 회복되어 솔방울 추출물 중 SFE에 서 얻은 추출물이 창상치유에 유용한 물질이 있음을 확인할 수 있 었다(Figure 5).

\section{9. 추출물 함유 에멀젼의 안정성 평가}

$\mathrm{WE}, \mathrm{EE}, \mathrm{SFE}$ 방법으로 얻은 추출물을 emulsion 제형에 첨가 하고 제형의 안정성(stability)을 측정하였다.

\section{1) $\mathrm{pH}$ 측정결과}

실온 $\left(25^{\circ} \mathrm{C}\right)$ 에서 보관한 각 추출물을 함유한 emulsion의 $\mathrm{pH}$ 를 28 일 동안 측정한 결과 Figure 6에 나타내었다. $\mathrm{WE}, \mathrm{EE}, \mathrm{SFE}$ 추 출물을 함유한 emulsion의 관찰기간에 따른 $\mathrm{pH}$ 의 변화는 없었다.

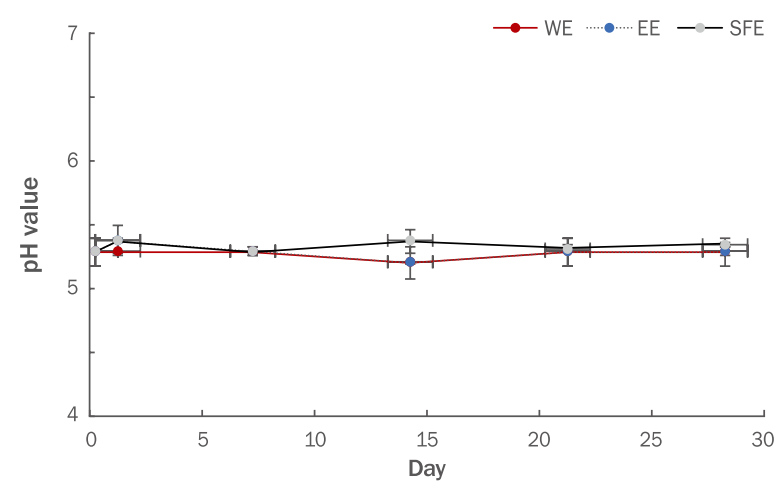

Figure 6. $\mathrm{pH}$ values of emulsion containing $0.5 \%$ pine cone extracts at $25^{\circ} \mathrm{C}$ condition.

The samples were determined by a digital $\mathrm{pH}$ meter. The $\mathrm{pH}$ measurements were also taken for the samples at $24 \mathrm{~h}$ on days 7, 14, 21 and 28. WE, water extract; EE, ethanol extract; SFE, supercritical fluid extract.

\section{2) 온도에 따른 안정성 시험결과}

화장품 제형 제조 시의 자발적인 경시적 열화 현상과 화학적, 물 리적 변화를 알아보기 위해서 $25,40^{\circ} \mathrm{C}$ 의 항온수조에 각각의 솔방 울추출물(WE, EE, $\mathrm{SFE})$ 을 함유한 emulsion을 보관하여 온도에 따른 안정성 측정결과, $\mathrm{SFE}$ 추출물을 첨가하여 제조한 emulsion 에서만 제조 후 28 일까지 변색, 발색, 변취, 응집, 산패 등의 변화 없이 각 온도 조건에서 안정성을 나타냈다. $\mathrm{WE}, \mathrm{EE}$ 추출물을 첨 가된 emulsion은 2 주가 경과되면서 상분리가 일어나는 것을 관찰 하였다.

\section{Conclusion}

본 연구는 추출방법에 따른 솔방울의 생리활성을 평가하고 화장 품에 응용하기 위한 가능성을 평가하였다.

솔방울의 생리활성 평가에서 솔방울의 총 폴리페놀 화합물 함량 
은 WE는 $180.75 \pm 1.83 \mathrm{mg} / \mathrm{g}, \mathrm{EE}$ 는 $252.69 \pm 0.34 \mathrm{mg} / \mathrm{g}, \mathrm{SFE}$ 는 $270.10 \pm 0.97 \mathrm{mg} / \mathrm{g}$ 으로 확인되었다. 특히 SFE로 얻은 추출물 은 비교적 높은 라디칼 소거능력을 보였다. 또한, 황색포도상구균 과 표피포도상구균에서 우수한 항균효과를 나타내었다. 각 추출물 의 세포독성평가 결과 $80 \%$ 이상의 세포생존율을 관찰하였다. 항염 증 실험에서 $\mathrm{SFE}$ 로 얻은 추출물이 가장 높은 항염 활성을 관찰하 였다. 또한 상처 치유능을 세포를 통해 관찰한 결과 $\mathrm{SFE}$ 를 처리한 그룹에서 세포 이동 및 증식률이 높은 것을 확인하였다. 이를 통해 $\mathrm{SFE}$ 방법으로 추출된 솔방울 성분은 항균, 항염, 재생등과 같은 기 능성 화장품원료로 활용 가능함을 확인할 수 있었다.

This work is part of the Jing-Gi Park M.D. thesis at the Chonnam University, Gwangju, Korea.

\section{Acknowledgements}

이 논문은 2019년 해양수산부 재원으로 해양수산과학기술진흥 원의 지원을 받아 수행된 연구임(골재생을 위한 해양유래 천연아 미노산 조성 흡수성 차폐막의 개발).

\section{References}

Berridge MV, Tan AS. Characterization of the cellular reduction of 3-(4,5-dimethylthiazol-2-yl)-2,5diphenyltetrazolium bromide (MTT): subcellular localization, substrate dependence, and involvement of mitochondrial electron transport in MTT reduction. Archives of Biochemistry and Biophysics, 303: 474-482, 1993.

Carson CF, Hammer KA. Chemistry and bioactivity of essential oils. In: Lipids and essential oils as antimicrobial agents. Thormar H (Ed.), John Wiley \& Sons, UK, pp203-238, 2011.

Cheng MC, Chang WH, Chen CW, Li WW, Tseng CY, Song TY. Antioxidant properties of essential oil extracted from Pinus morrisonicola hay needles by supercritical fluid and identification of possible active compounds by GC/ MS. Molecules, 20: 19051-19065, 2015.

Choi J, Lee B, Lee D, Choi I. Growth monitoring of Korean white pine (Pinus koraiensis) plantation by thinning intensity. Journal of Korean Society of Forest Science, 103: 422-430, 2014.
Cho S, Kim O. Antioxidative activity and protein expression effects of the extracts from Cinnamomum camphora on the hair-growth relevant factors. Asian Journal of Beauty and Cosmetology, 14: 18-29, 2016.

Hwang HS, Hwang TH, Pyo AJ, Ju EW. Anti-oxidant Efficacy and effects on expression of growth factors in human hair follicle dermal papilla cells of Rosa multiflora root extracts. Asian Journal of Beauty and Cosmetology, 15: 146-158, 2017.

Hong EJ, Na KJ, Choi IG, Choi KC, Jeung EB. Antibacterial and antifungal effects of essential oils from coniferous trees. Biological and Pharmaceutical Bulletin, 27: 863866, 2004.

Jeong KH, Hwang IS, Kim JE, Lee YJ, Kwak MH, Lee YH, Lee $J H$, Hwang DY, Jung YJ. Anti-bacterial effects of aqueous extract purified from the immature cone of red pine (Pinus densiflora). Textile Coloration and Finishing, 26: 45-52, 2014.

Lee MY, Yoo MS, Whang YJ, Jin YJ, Hong MH, Pyo YH. Vitamin C, total polyphenol, flavonoid contents and antioxidant capacity of several fruit peels. Korean Journal of Food Science and Technology, 44: 540-544, 2012.

Ryu BS, Cho HE, Choi WS, Lee NH, Choi UK. Antioxidant activities of extracts from different parts of the pine tree. The Korean Journal of Food and Nutrition, 30: 1133-1139, 2017.

Marxen K, Vanselow KH, Lippemeier S, Hintze R, Ruser A, Hansen UP. Determination of DPPH radical oxidation caused by methanolic extracts of some microalgal species by linear regression analysis of spectrophotometric measurements. Sensors (Basel), 7: 2080-2095, 2007.

Park SM, Byun SH, Kim YW, Cho IJ. Inhibitory effect of Mori Folium ethanol extract on pro-inflammatory mediator in lipopolysaccharide-activated RAW 264.7 cells. The Korea Journal of Herbology, 27: 31-38, 2012.

Palmer MV, Ting SST. Applications for supercritical fluid technology in food processing. Food Chemistry, 52: 345352, 1995.

Zuo J, Li Q, Dong ZY, Meng H, Li L, Dong YM. Preparation of self microemulsion of ferulic acid. Asian Journal of Beauty and Cosmetology, 15: 345-353, 2017. 


\section{국문초록}

\section{솔방울 추출물의 파이토케미컬 성분 평가 및 $\mathrm{HaCaT}$ 세포이동 평가}

김진 ${ }^{1,5}$, 박징기 ${ }^{2}$, 이창문 ${ }^{3,4 *}$, 김수관 ${ }^{1,5 *}$

${ }^{1}$ 조선대학교 치과대학 구강악안면외과학교실, 광주, 한국

${ }^{2}$ (주머니키, 광주, 한국

${ }^{3}$ 전남대학교 의공학과, 전라남도 여수시, 한국

${ }^{4}$ 전남대학교 헬스케어의공학연구소, 전라남도 여수시, 한국

${ }^{5}$ 조선대학교 치의학연구소, 광주, 한국

목적: 본 연구는 솔방울(pine cone)을 화장품 소재로서의 활용가능성을 확인하기 위하여 열수(WE), 주정(EE), 초임계방법(SFE)으 로 추출하여 비교 실험을 진행하였다. 방법: 각 추출방법으로 얻은 추출물의 파이토케미컬 성분을 확인하고자GC/MS로 분석하였 고, 총 폴리페놀 함량과 2,2-diphenyl-1-picrylhydrazyl (DPPH) 라디칼소거능으로 항산화 활성을 측정하였다. 또한 항균 및 항염 증 효과를 비교 분석하였으며, 각 추출물을 에멀젼 제형에 첨가하여 안정성을 확인하였다. 결과: 총 폴리페놀 함량 측정한 결과 $\mathrm{WE}$ 는 $180.75 \pm 1.83 \mathrm{mg} / \mathrm{g}$, EE는 $252.69 \pm 0.34 \mathrm{mg} / \mathrm{g}, \mathrm{SFE}$ 는 $270.10 \pm 0.97 \mathrm{mg} / \mathrm{g}$ 이 확인되었다. DPPH법을 이용한 항산화 효과 측 정 시 SFE로 얻은 추출물이 저농도(0.125\%)에서도 높은 항산화 능력을 나타내었다. 솔방울 추출물의 항균 효과를 측정한 결과 $\mathrm{SEF}$ 추출물은 $\mathrm{SA}$ 에서 $12.1 \pm 1.04 \mathrm{~mm}, \mathrm{SE}$ 에서 $11.8 \pm 0.45 \mathrm{~mm}$ 의 clear zone이 확인이 되어 기타 $\mathrm{WE}$ 와 $\mathrm{EE}$ 추출물보다 높은 항균효과 를 나타내었다. 세포독성 평가 결과 모든 추출물에서 $80 \%$ 이상의 세포생존율을 관찰하였다. 항염 실험에서 추출물 처리 시 LPS 처 리군에 비해 nitric oxide 발현량이 유의성 있게 감소함을 확인하였다. 솔방울 추출물을 첨가한 에멀젼을 제조하여 안정성을 관찰한 결과 $\mathrm{SFE}$ 추출물을 첨가한 emulsion만이 $\mathrm{pH}$ 및 고온 $\left(40^{\circ} \mathrm{C}\right)$ 에서 안정함이 확인이 되었다. 결론: 본 연구를 통해 솔방울SFE추출물 의 항염 및 피부재생 효과를 확인하였고, 앞으로 항염증 및 피부 재생 화장품 원료로서의 응용이 가능할 것으로 사료된다.

핵심어: 솔방울, 파이토케미컬, 초임계추출장치, 항염증, 코스메디컬

이 논문은 2019년 해양수산부 재원으로 해양수산과학기술진흥원의 지원을 받아 수행된 연구임(골재생을 위한 해양유래 천 연아미노산 조성 흡수성 차폐막의 개발).

\section{참고문헌}

박상미, 변성희, 김영우, 조일제, 김상찬. 상엽추출물의 LPS로 유도된 RAW2647 세포에서의 항염증 효과. 대한본초학회 지, 27: 31-38, 2012.

이민영, 유미소, 황유정, 진유정, 홍명희, 표영희. 과일 껍질의 비타민C, 폴리페놀, 플라보노이드 함량과 항산화 활성. 한 국식품과학회지, 44: 540-544, 2012.

유범석, 최희은, 최원석, 이난희, 최웅규. 소나무 부위별 추출물의 항산화 활성. 한국식품영양학회지, 30: 1133-1139, 2017.

정경희, 황인식, 김지은, 이영주, 곽문화, 이영희, 이재호, 황대연, 정연진. 미성숙 솔방울 열수추출물의 항균성. 한국염색 가공학회지, $26: 45-52,2014$.

조솔, 김옥환. 모발성장요소에 대한 녹나무추출물의 항산화능 및 단백질 발현 효능. 아시안뷰티화장품학술지, $14: 18-29$, 2016.

좌금휘, 이강, 동탁원, 맹홍, 리려, 동은묘. 페룰산의 마이크로 에멀젼 제조공정에 관한 연구. 아시안뷰티화장품학술지, 15: 345-353, 2017. 
Phytochemical Effects and Physiological activity of the Pine Cone Extract

최정기, 이병기, 이대성, 최인화. 간벌강도에 따른 잣나무 인공림의 생장변화 모니터링. 한국산림과학회지, 103: 422$430,2014$.

황현숙, 황태현, 표애자, 주은화. 찔레뿌리 추출물의 항산화능과 인간모유두세포의 성장인자 발현에 미치는 영향. 아시안 뷰티화장품학술지, 15: 146-158, 2017. 


\section{中文摘要}

\section{松果提取物的植物化学成分以及HaCaT细胞迁移的评估}

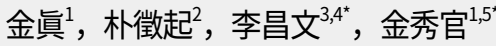

1朝鲜大学牙科学院口腔领面外科, 光州, 韩国

${ }^{2}$ (株) Moneykey, 光州, 韩国

3 全南大学医学工程学科, 全罗南道丽水市, 韩国

全南大学健康管理医科工学研究所, 全罗南道丽水市, 韩国

全南大学牙科研究所, 光州, 韩国

目的：探讨松果提取物作为生物活性成分和化妆品成分时的性质和潜在的商业价值。方法：用热水（WE），70\% 乙醇 (EE) 和超临界流体萃取 (SFE) 提取松果, 为了确定每种提取方法获得的提取物的植物化学成分，通过 GC/MS进行了分析, 并通过总多酚含量和2,2-二苯基-1-吡啶并肼基（DPPH）自由基清除能力来测定抗氧化活 性。另外, 比较和分析了抗微生物和抗炎作用, 并将每种提取物添加到乳液配方中以确认稳定性。结果: 测量 总多酚含量的结果：WE为 $180.75 \pm 1.83 \mathrm{mg} / \mathrm{g}, \mathrm{EE}$ 为 $252.69 \pm 0.34 \mathrm{mg} / \mathrm{g}$, SFE为 $270.10 \pm 0.97 \mathrm{mg} / \mathrm{g}$ 。通过 DPPH法测定抗氧化效果时，即使在低浓度 $(0.125 \%)$ 下，通过SFE获得的提取物也显示出高抗氧化能力。 测量松果提取物的抗菌效果的结果是, SEF提取物在SA中显示出 $12.1 \pm 1.04 \mathrm{~mm}$ 的透明区域，在SE中显示出 $11.8 \pm 0.45 \mathrm{~mm}$ 的透明区域，显示出比其他WE和EE提取物更高的抗菌效果。细胞毒性评估的结果，在所有提取 物中均观察到 $80 \%$ 以上的细胞生存率。在抗炎实验中，证实了与LPS治疗组相比，一氧化氮的表达显着降低。 制备含有松果提取物的乳液并观察到稳定性的结果, 证实了仅含有SFE提取物的乳液在 $\mathrm{pH}$ 和高温 $\left(40^{\circ} \mathrm{C}\right)$ 下是 稳定的。结论: 这些研究结果表明, SFE提取物是一种可能的药妆材料，具有强大的皮肤再生和抗炎特性。

关键词: 松果, 植物化学, 超临界流体萃取, 消炎, 药妆 
